\title{
Hemato-biochemical and Physiological Response of Barbari Kids to Different Bedding Materials during Winter
}

\author{
Mohit Antil ${ }^{\text {* }}$, Bhuvaneshwar Rai ${ }^{2}$, Natesan Ramachandran ${ }^{2}$, \\ Chetna Gangwar ${ }^{2}$ and Arun Somagond ${ }^{1}$ \\ ${ }^{1}$ Livestock Production Management division, Indian Veterinary Research Institute \\ Izatnagar, Bareilly-243122, India \\ ${ }^{2}$ Animal Physiology and Reproduction division, Central Institute for Research on Goats, \\ Makhdoom, Mathura-281122, India \\ *Corresponding author
}

\section{A B S T R A C T}

The comparative haemato-biochemical and physiological response to different bedding materials in Barbari kids was evaluated. Thirty post-weaned Barbari kids of about three months age were selected from the institutional flock, which were divided into three

\section{Keywords}

Bedding material, Haematobiochemical, Physiological, Barbari goat kids, Winter season

Article Info

Accepted:

15 January 2019

Available Online:

10 February 2019 groups viz. group I, II and III with ten kids in each group and were kept on plastic slats, soil and rubber mats, respectively. Blood samples were taken at monthly interval during the trial. There was no significant effect of flooring type on the physiological parameters. The mean values of hemoglobin $(\mathrm{g} / \mathrm{dl})$ and hematocrit $(\%)$ were 9.00, 8.93, 8.96 and 22.04, 21.68, and 21.95, in group I, II and III, respectively. The values of RBC, WBC, lymphocytes, monocytes and granulocytes counts were 15.36, 14.73, $14.97\left(\mathrm{~m} / \mathrm{mm}^{3}\right)$ and $14.43,12.66,13.71\left(\mathrm{~m} / \mathrm{mm}^{3}\right)$ and $41.56,46.03,46.37(\%)$ and $4.82,5.23,5.28(\%)$ and $53.61,48.74$ and $48.32(\%)$, in group I, II and III respectively. The mean total protein, albumin and globulin values were 6.85, 6.45, $6.34(\mathrm{~g} / \mathrm{dl})$ and 2.59, 2.46 and $2.42(\mathrm{~g} / \mathrm{dl})$ and $4.25,3.98$ and $3.91(\mathrm{~g} / \mathrm{dl})$ in group I, II and III, respectively. The mean values of plasma glucose, triglycerides and cholesterol were 63.63, 66.32, $70.14(\mathrm{mg} / \mathrm{dl})$ and 90.29, 96.90, $90.51(\mathrm{mg} / \mathrm{dl})$ and $82.49,82.94$ and $86.51(\mathrm{mg} / \mathrm{dl})$ in group I, II and III, respectively. The concentration of glucose was comparable $(\mathrm{P}>0.05)$ among group I and II and also among group II and III, whereas significantly different $(\mathrm{P}<0.05)$ among group I and III. The mean values of total protein in group I was significantly higher $(\mathrm{P}<0.05)$ than group II and III. The mean values of triglycerides were significantly higher $(\mathrm{P}<0.05)$ in group II as compared to group I and III.

\section{Introduction}

One of the most coherent reasons for preference of goats, as compared to other domestic species, among small and marginal farmers of India for their livelihood is their adaptability to wide range of climatic conditions (Devendra, 1990; Rekib, 1998). Goats are well-adapted to all types of environmental severities and exhibit superior performance over the other domesticated ruminants (Shkolnik and Silanikove, 1981; 
King, 1983). The survival of goats at very high as well as very low temperatures has been ensured by their well-developed adaptive mechanisms. However, despite their adaptability to climatic adversities, thermal stress often results in reduction of their productivity (Al-Tamimi, 2007).

The main problem of kid rearing is the postweaning stress leading to poor growth which is significantly affected by housing management (Dadi et al., 2008; Gbangboche et al., 2006). The poor building designs and inappropriate microclimates can result in thermal stress, which significantly affects the efficiency of animal production (Clark and McArthur, 1994). Different management systems can be assessed by using physiology and hematology as effective tools and indicators of optimum health and production. Bedding material is a key component in housing of kids during winters and can contribute to enhancement of animal welfare and health (Behera et al., 2016). Usage of inadequate bedding during winters, which consequentially impedes the productivity of livestock making them prone to different diseases and parasitic infestation (internal and external)

In this outset, we aimed to assess and compare the important hematological and physiological parameters of Barbari kids attributing adaptable characters in cold climates maintained in intensive management system.

\section{Materials and Methods}

The present study was conducted at Experimental shed complex on ICAR-Central Institute for Research on Goat (C.I.R.G) Makhdoom, Mathura, Uttar Pradesh, India. The climate is hot and semi-arid. Weather turns colder with winter stretching from November to February and summer ranges from May to August month annually.
The animal experiment was initiated in December 2017 and ended in March 2018. A total of 30 post weaned Barbari kids (21 males and 9 females) aged 3 months were selected from institute flock. The kids were randomly allocated to the two treatment groups (Plastic slats and rubber mat) and one control group (Soil floor) on the basis of similar body weight (Table 1).

Each group comprised of ten kids (7 males and 3 females). While selecting the animals, due care was taken to minimize the error by narrowing down the range of age and live weights of these experimental animals as far as possible. The study was conducted for a period of 90 days duration with an adaptation period of 1 week prior to recording of variables. The animals were raised under an intensive housing system. A single pen (400 feet ${ }^{2}$ ) was partitioned equally into 4 parts using welded wire mesh. The control and treatment groups were housed in separate partition of the pen having different bedding materials. Out of the three groups, second group served as control.

\section{Physiological parameters}

The following parameters were recorded fortnightly at 9 AM for two consecutive days.

Rectal temperature (RT): The rectal temperature was recorded by using clinical thermometer.

Respiration rate (RR): The respiration rate per minute was recorded by counting the movement of flank i.e., one outward and inward movement as one respiration.

Heart rate (HR): The heart rate per minute was counted by stethoscope or placing the hand over the heart with minimum disturbance to the animal. 


\section{Blood collection, preservation and analysis}

Blood samples were collected on 20th, 50th and 80th day of experimental trail. About 10 $\mathrm{ml}$ blood was collected from all the experimental kids in the morning (before feeding) by jugular vein puncture. Blood flow was stopped by applying finger pressure on a gauze pad on the blood sampling site till the bleeding was stopped. Blood was taken in another clean and dry test tube containing anticoagulant (EDTA) for hematology and separation of plasma for biochemical estimation.

The blood samples were brought to the laboratory and centrifuged at $3000 \mathrm{rpm}$ for 15 min to separate plasma collected in small plastic eppendorf tubes $(2 \mathrm{ml})$ and stored at $20^{0} \mathrm{C}$ for further analysis. The plasma samples were analyzed for different biochemical constituents viz. glucose, total protein, albumin, triglycerides and total cholesterol using diagnostic kits manufactured by Cogent $^{\mathrm{TM}}$ of Span Diagnostic Ltd. Surat, Gujarat, India. The procedure provided by the company on kits leaflet was strictly followed for analysis.

\section{Results and Discussion}

\section{Physiological parameters}

The values of the physiological parameters have been presented in Table 2. The overall mean values of respiration rate (RR) were $33.70,32.00$ and 35.13, respectively in Gr-I, II and III. The values of RR were comparable ( $\mathrm{P}>0.05)$ among the groups. The overall mean values of heart rate (HR) were 124.61, 130.46 and 129.33, respectively in Gr-I, II and III. The values of HR were comparable $(\mathrm{P}>0.05)$ among the groups. The overall mean values of RT were $38.82,38.78$ and 38.62 , respectively in Gr-I, II and III. The values of RT were comparable $(\mathrm{P}>0.05)$ among the groups.

\section{Haematological parameters}

The mean values of different hematological parameters studied during the trial have been presented in Table 3. There was no significant difference between the groups in white blood cells (WBC), hemoglobin ( $\mathrm{Hb}$ ), red blood cells (RBC), hematocrit (HCT), lymphocyte, monocyte and granulocyte values. The mean values of hemoglobin $(\mathrm{g} / \mathrm{dl})$ and hematocrit (\%) were $9.00,8.93,8.96$ and $22.04,21.68$, and 21.95, in Gr-I, II and III, respectively.

Table.1 Dimensions of partitions of pen made for different groups

\begin{tabular}{|l|l|l|}
\hline Group & Bedding material used & Dimensions of partition \\
\hline $\mathbf{1}$ & Plastic Slats & 10 feet $\times 10$ feet \\
\hline $\mathbf{2}$ & Soil & 10 feet $\times 10$ feet \\
\hline $\mathbf{3}$ & Rubber mats & 10 feet $\times 10$ feet \\
\hline
\end{tabular}

Table.2 Effect of different physiological parameters of kids in different groups

\begin{tabular}{|l|l|l|l|l|l|l|}
\hline & Group I & Group II & Group III & Mean & SEM & P Value \\
\hline Respiration rate (breaths/min) & 33.70 & 32.00 & 35.13 & 33.61 & 0.71 & 0.198 \\
\hline Heart rate (beats/min) & 124.61 & 130.46 & 129.33 & 128.13 & 1.12 & 0.079 \\
\hline Rectal temperature $\left({ }^{\circ} \mathbf{C}\right)$ & 38.82 & 38.78 & 38.62 & 38.74 & 0.03 & 0.082 \\
\hline
\end{tabular}

${ }_{A, B, C}$ Means bearing different superscripts in a row differ significantly $(p<0.05)$ 
Table.3 Effect of bedding materials on haematological parameters of kids in different groups

\begin{tabular}{|c|c|c|c|c|c|}
\hline \multirow[t]{2}{*}{ Attributes } & \multicolumn{3}{|c|}{ Groups } & \multirow[t]{2}{*}{ SEM } & \multirow[t]{2}{*}{ P Value } \\
\hline & I & II & III & & \\
\hline \multicolumn{6}{|c|}{ Red Blood Corpuscles $\left(\mathrm{m} / \mathrm{mm}^{3}\right)$} \\
\hline 20 day & 14.77 & 14.26 & 14.54 & 0.12 & 0.139 \\
\hline 50 day & 15.31 & 14.83 & 14.88 & & \\
\hline 80 day & 15.99 & 15.10 & 15.49 & & \\
\hline Mean value & 15.36 & 14.73 & 14.97 & & \\
\hline \multicolumn{6}{|c|}{ Hemoglobin (g/dl) } \\
\hline 20 day & 8.88 & 8.77 & 9.04 & 0.07 & 0.943 \\
\hline 50 day & 9.30 & 9.36 & 9.25 & & \\
\hline 80 day & 8.83 & 8.68 & 8.59 & & \\
\hline Mean value & 9.00 & 8.93 & 8.96 & & \\
\hline \multicolumn{6}{|c|}{ Hematocrit (\%) } \\
\hline 20 day & 20.14 & 19.18 & 20.36 & 0.25 & 0.846 \\
\hline 50 day & 21.94 & 22.32 & 21.74 & & \\
\hline 80 day & 24.05 & 23.56 & 23.76 & & \\
\hline Mean value & 22.04 & 21.68 & 21.95 & & \\
\hline \multicolumn{6}{|c|}{ White Blood Corpuscles $\left(\mathrm{m} / \mathrm{mm}^{3}\right)$} \\
\hline 20 day & 15.40 & 13.34 & 14.16 & 0.32 & 0.80 \\
\hline 50 day & 13.57 & 12.88 & 13.95 & & \\
\hline 80 day & 14.33 & 11.77 & 13.01 & & \\
\hline Mean value & 14.43 & 12.66 & 13.71 & & \\
\hline \multicolumn{6}{|c|}{ Lymphocytes (\%) } \\
\hline 20 day & 34.88 & 38.82 & 39.98 & 1.14 & 0.160 \\
\hline 50 day & 39.28 & 45.00 & 42.97 & & \\
\hline 80 day & 50.53 & 54.27 & 56.18 & & \\
\hline Mean value & 41.56 & 46.03 & 46.37 & & \\
\hline \multicolumn{6}{|c|}{ Monocytes (\%) } \\
\hline 20 day & 4.33 & 4.66 & 4.74 & 0.10 & 0.139 \\
\hline 50 day & 4.95 & 5.25 & 4.89 & & \\
\hline 80 day & 5.18 & 5.79 & 6.23 & & \\
\hline Mean value & 4.82 & 5.23 & 5.28 & & \\
\hline \multicolumn{6}{|c|}{ Granulocytes (\%) } \\
\hline 20 day & 60.79 & 56.52 & 55.24 & 1.18 & 0.129 \\
\hline 50 day & 55.77 & 49.77 & 52.14 & & \\
\hline 80 day & 44.29 & 39.94 & 37.59 & & \\
\hline Mean value & 53.61 & 48.74 & 48.32 & & \\
\hline
\end{tabular}


Table.4 Effect of bedding materials on plasma biochemical parameters of kids in different groups

\begin{tabular}{|c|c|c|c|c|c|}
\hline \multirow[t]{2}{*}{ Attributes } & \multicolumn{3}{|c|}{ GROUPS } & \multirow[t]{2}{*}{ SEM } & \multirow[t]{2}{*}{ P Value } \\
\hline & I & II & III & & \\
\hline \multicolumn{6}{|c|}{ Glucose (mg/dl) } \\
\hline 20 day & 64.84 & 65.36 & 67.91 & 0.89 & 0.01 \\
\hline 50 day & 59.91 & 64.59 & 70.86 & & \\
\hline 80 day & 66.14 & 68.99 & 71.66 & & \\
\hline Mean value & $63.63^{\mathrm{B}}$ & $66.32^{\mathrm{AB}}$ & $70.14^{\mathrm{A}}$ & & \\
\hline \multicolumn{6}{|c|}{ Triglyceride(mg/dl) } \\
\hline 20 day & 88.23 & 97.21 & 85.94 & 1.09 & 0.019 \\
\hline 50 day & 87.07 & 94.78 & 90.72 & & \\
\hline 80 day & 95.57 & 98.71 & 94.87 & & \\
\hline Mean value & $90.29^{B}$ & $96.90^{\mathrm{A}}$ & $90.51^{B}$ & & \\
\hline \multicolumn{6}{|c|}{ Total protein $(\mathrm{g} / \mathrm{dl})$} \\
\hline 20 day & 6.83 & 6.56 & 6.37 & 0.06 & 0.002 \\
\hline 50 day & 6.97 & 6.30 & 6.14 & & \\
\hline 80 day & 6.74 & 6.49 & 6.52 & & \\
\hline Mean value & $6.85^{\mathrm{A}}$ & $6.45^{\mathrm{B}}$ & $6.34^{\mathrm{B}}$ & & \\
\hline \multicolumn{6}{|c|}{$\operatorname{Albumin}(\mathrm{g} / \mathrm{dl})$} \\
\hline 20 day & 2.48 & 2.36 & 2.30 & 0.03 & 0.106 \\
\hline 50 day & 2.68 & 2.43 & 2.47 & & \\
\hline 80 day & 2.61 & 2.59 & 2.51 & & \\
\hline Mean value & 2.59 & 2.46 & 2.42 & & \\
\hline \multicolumn{6}{|c|}{ Globulin (g/dl) } \\
\hline 20 day & 4.34 & 4.20 & 4.06 & 0.06 & 0.107 \\
\hline 50 day & 4.29 & 3.86 & 3.67 & & \\
\hline 80 day & 4.12 & 3.90 & 4.01 & & \\
\hline Mean value & 4.25 & 3.98 & 3.91 & & \\
\hline \multicolumn{6}{|l|}{ AG Ratio } \\
\hline 20 day & 0.57 & 0.57 & 0.58 & 0.01 & 0.904 \\
\hline 50 day & 0.64 & 0.65 & 0.69 & & \\
\hline 80 day & 0.66 & 0.69 & 0.66 & & \\
\hline Mean value & 0.62 & 0.64 & 0.64 & & \\
\hline \multicolumn{6}{|c|}{ Cholesterol (mg/dl) } \\
\hline 20 day & 72.46 & 72.24 & 74.27 & 1.57 & 0.524 \\
\hline 50 day & 78.33 & 80.19 & 85.17 & & \\
\hline 80 day & 96.69 & 96.38 & 100.1 & & \\
\hline Mean value & 82.49 & 82.94 & 86.51 & & \\
\hline
\end{tabular}

${ }^{A, B, C}$ Means bearing different superscripts in a row differ significantly $(p<0.05)$ 
The values of RBC, WBC, lymphocytes, monocytes and granulocytes counts were 15.36, 14.73, $14.97\left(\mathrm{~m} / \mathrm{mm}^{3}\right)$ and 14.43, $12.66,13.71\left(\mathrm{~m} / \mathrm{mm}^{3}\right)$ and $41.56,46.03,46.37$ (\%) and 4.82, 5.23, $5.28(\%)$ and 53.61, 48.74 and $48.32(\%)$, in Gr-I, II and III respectively. All the values were within the normal reference range for kids (Feldman et al., 2002).

\section{Hemato-biochemical parameters}

The effect of different bedding materials on blood biochemical parameters viz., plasma glucose, triglycerides, total protein, albumin, globulin, A/G ratio and cholesterol has been presented in table 3 . The mean total protein (TP), albumin and globulin values were 6.85 , 6.45, $6.34(\mathrm{~g} / \mathrm{dl})$ and 2.59, 2.46 and $2.42(\mathrm{~g} / \mathrm{dl})$ and $4.25,3.98$ and $3.91(\mathrm{~g} / \mathrm{dl})$ in Gr-I, II and III, respectively. The mean value of albumin: globulin ratio was $0.62,0.64$, and 0.64 , respectively in Gr-I, II and III.

The mean values of plasma glucose, triglycerides and cholesterol were 63.63, 66.32, $70.14(\mathrm{mg} / \mathrm{dl})$ and 90.29, 96.90, 90.51 $(\mathrm{mg} / \mathrm{dl})$ and $82.49,82.94$ and $86.51(\mathrm{mg} / \mathrm{dl})$ in Gr-I, II and III, respectively. The concentration of glucose was comparable (P>0.05) among Gr-I and II and also among Gr-II and III, whereas significantly different $(\mathrm{P}<0.05)$ among Gr-I and III. The mean values of total protein in Gr-I was significantly higher $(\mathrm{P}<0.05)$ than $\mathrm{Gr}-\mathrm{II}$ and III. The mean values of triglycerides were significantly higher $(\mathrm{P}<0.05)$ in $\mathrm{Gr}$ II as compared to Gr I and III (Table 4).

\section{Physiological parameters}

The values of $\mathrm{RR}, \mathrm{HR}$ and $\mathrm{RT}$ were comparable $(\mathrm{P}>0.05)$ among the groups. Similarly, Thiruvenkadan et al., (2009) reported no significant effects of flooring type on physiological parameters in Tellicherry goats. But seasonal variations were significant, as in summers animals exhibited higher respiration as well as pulse rate. These changes might have aroused due to effect of environmental temperatures and metabolic rates. Jagadale (1981) also reported similar findings in Beetal goats. On the contrary, Behera et al., (2016) in Black Bengal goats; Muller and Botha (1994) in Friesian cows; Patel et al., (2007) in Marwari kids and Singh et al., (2008) in sheep, observed significant differences in the physiological parameters due to floor type.

\section{Hemato-biochemical parameters}

There was no significant difference between the groups in white blood cells (WBC), hemoglobin $(\mathrm{Hb})$, red blood cells (RBC), hematocrit (HCT), lymphocyte, monocyte and granulocyte values. Similarly, Abdelatif et al., (2009) reported that mean cell volume (MCV) and haemoglobin were significantly higher with drop in ambient temperature and total leukocyte count (TLC) was not affected significantly by the thermal environment. On the contrary, Thiruvenkadan et al., (2009) observed lower hemoglobin values in kids raised on different type of floors during winters.

Blood biochemical variables such as glucose, total protein, cholesterol, albumin, and triglyceride may be vital indicator to establish effects of stress on animals (Sejian and Srivastava, 2010). The concentration of glucose was comparable ( $\mathrm{P}>0.05)$ among Gr-I and II and also among Gr-II and III, whereas significantly different $(\mathrm{P}<0.05)$ among Gr-I and III. The mean values of total protein in Gr-I were significantly higher $(\mathrm{P}<0.05)$ from Gr-II and III. The mean values of triglycerides were significantly higher $(\mathrm{P}<0.05)$ in Gr II as compared to Gr I and III.

Most of the workers are in agreement with our findings, Nazifi et al., (2002) and Pandey et al., (2012) observed significant reduction in 
triglyceride levels during cold stress than animal kept at optimum temperature. Coop and Holmes (1996) and Singh et al., (2017) found similar values for total protein. The possible reason for lower protein values in rubber and soil bedding is reduced efficiency of feed utilization due to increased parasitic load, characterized by increased endogenous protein loss into the gastrointestinal tract. During increased parasitic load repair processes such as regeneration of gastrointestinal tract mucosa, plasma proteins synthesis and mucoprotein production predominates over productive.

Based on the research results it can be concluded that blood $\mathrm{Hb}, \mathrm{RBC}, \mathrm{PCV}, \mathrm{WBC}$, lymphocyte, monocyte, granulocyte and plasma albumin, globulin, $\mathrm{A} / \mathrm{G}$ ratio and cholesterol were comparable $(\mathrm{P}>0.05)$ among the different groups. There was no significant effect of flooring type on the physiological parameters in Barbari kids. Plasma total protein levels were significantly higher $(\mathrm{P}<0.05)$ in $\mathrm{Gr}-\mathrm{I}$ as compared to Gr II and III. Plasma glucose levels were significantly higher $(\mathrm{P}<0.05)$ in Gr-III as compared to Gr I and II. Plasma triglycerides found to be significantly higher $(\mathrm{P}<0.05)$ in $\mathrm{Gr}$ II as compare to Gr I and III. They may indicate towards presence of stressors i.e. lower floor temperature in $\mathrm{Gr} \mathrm{I}$ and higher disease incidence in Gr III, respectively. Provision of different bedding materials viz. plastic slats, rubber and soil had similar effect on performance of the Barbari kids in terms of physiology and blood biochemical parameters, however, plastic slats improved the hygienic aspects in kids.

\section{References}

Abdelatif, A.M., Ibrahim M.Y., Hassan Y.Y. 2009. Seasonal variation in erythrocytic and leukocytic indices and serum proteins of female Nubian goats. Middle East J. Sci. Res. 4(3): 168-174.

Al-Tamimi H.J. 2007. Thermoregulatory response of goat kids subjected to heat stress. Small Rumin Res. 71:280-285.

Behera, K., Kumar, V., Pradhan, C.R., Sethy, K., Behera, D. and Panigrahy, K.K., 2016. Ameliorative measure for cold in Black Bengal goats in coastal Odisha climate. Indian J. Anim. Prod. Mgmt. 32(1-2): 8-13.

Clark, J.A., McArthur, A.J., 1994. Thermal exchanges. In: Wathes, C.M., Charles, D.R. (Eds.), Livestock Housing. CAB International, Wallingford, pp. 97122.

Coop, R.L. and Holmes, P.H. 1996. Nutrition and parasite infection. Int. J. Para. 26: 951-962.

Dadi H., Duguma G., Shelima B., Fayera T., Tadesse M., Woldu T and Tucho T.A. 2008: Non-genetic factors influencing post-weaning growth and reproductive performances of Arsi-Bale goats. Volume 20, Article \#114. Retrieved January 30, 2019, from http://www.lrrd.org/lrrd20/7/dadi2011 4.htm

Devendra C. 1990. Comparative aspects of digestive physiology and nutrition in goats and sheep. In: Devendra C., Imazumi E., editors. Ruminant Nutrition and Physiology in Asia. p. 45-60.

Feldman, B.F., Zink, J.G. and Jain, N.C. 2002. Schalm's Veterinary Hematology. Philadelphia. Baltimore, New York, London, Buenos Aires, Hong Kong, Sidney.

Gbangboche A.B., Adamou-Ndiaye M., Youssao A.K.I., Farnir F., Detilleux J., Abiola F.A. and Leroy P.L. 2006 Nongenetic factors affecting the reproduction performance, lamb growth and productivity indices of Djallonke sheep. Small Rum. Res. 64 
(1) 133-142.

Jagadale, P.N. 1981. Effect of different housing system on the performance of lactating Beetal goats. M.Sc. Thesis, NDRI, Karnal.Haryana-132001.

King, J.M. 1983. Livestock water needs in pastoral Africa in relation to climate and forage. Res. Report No. 7. Addis Ababa (Ethiopia): Int. Lives Center Africa (ILCA).

Muller, C.J.C and Botha, J.A. 1994. Effect of shade on various parameters of Friesian cows in a Mediterranean climate in South Africa. Feed and water intake, milk production and milk composition. S. Aft .J. Anim. Sci. 24(2): 56-60.

Nazifi, S., Gheisari, H.R. and Shaker, F. 2002. Serum lipids and lipoproteins and their correlations with thyroid hormones in clinically healthy goats. Veterinarski Arch. 72: 249-257.

Pandey, N., Kataria, N., Kataria, A.K. and Joshi, A. 2012. Ambient stress associated variations in metabolic responses of Marwari goat of arid tracts in India. J. Stress Physio. Biochem. 8: 120-127.

Patel, A.K., Rohilla, P.P. and Mathur, A.C. 2007. Performance of Marwari kids and goats under improved and traditional animal shelter. Indian Vet. J. 84: 1069-1071.

Rekib A. 1998. Grazing resources and livestock productivity with special reference to goat production. Ind $\mathrm{J}$ Anim Sci. 68:846-848.

Sejian, V. and Srivastava, R.S. 2010. Effects of melatonin on adrenal cortical functions in Indian goats under thermal stress. Veterinary Medicine International Article ID 348919.

Shkolnik A, Silanikove N. 1981. Water economy, energy metabolism and productivity in desert ruminants. In: Morand-Fehr P, Borbouse A, De Simiane M, editors. Nutrition and systems of goat feeding. Tours, France: ITOVIC-INRA; vol. 1; $\mathrm{p}$. 236-246.

Singh, D.V., Singh, S.K., Patel, M. and Kumar A. 2008. A new dimension to comfortable housing of goats in Tarai region. The Indian J. Anim. Prod. Mgmt. 24(3-4): 120-123.

Singh, S.P., Ramachandran, N., Tripathi, M.K. and Bhushan, S. 2017. Physiological, biochemical and endocrine response of goat kids maintained on two different floor types in hot-dry weather conditions. Indian J. Ani. sci. 87(2): 223-228.

Thiruvenkadan, A.K., Murugan, M., Karunanithi K., Muralidharan J., Chinnamani K. 2009. Genetic and non-genetic factors affecting body weight in Tellicherry goats. South African J Anim Sci. 39(Suppl. 1): 107-111.

\section{How to cite this article:}

Mohit Antil, Bhuvaneshwar Rai, Natesan Ramachandran, Chetna Gangwar and Arun Somagond. 2019. Hemato-biochemical and Physiological Response of Barbari Kids to Different Bedding Materials during Winter. Int.J.Curr.Microbiol.App.Sci. 8(02): 1829-1836. doi: https://doi.org/10.20546/ijcmas.2019.802.214 